\title{
PENGEMBANGAN BAHAN AJAR BIOLOGI TERINTEGRASI IMTAQ PADA MATERI VERTEBRATA SESUAI KURIKULUM 2013 KELAS X SMA
}

\author{
Novi Irmania ${ }^{1)}$, Raharjo ${ }^{2)}$, Suyono ${ }^{3)}$ \\ ${ }^{1)}$ Mahasiswa Program Studi Pendidikan Sains, Program Pascasarjana Universitas Negeri Surabaya \\ ${ }^{2), 3)}$ Dosen Pascasarjana Prodi Pendidikan Sains Univesrtitas Negeri Surabaya \\ E-mail: irmania.novi@gmail.com
}

\begin{abstract}
The research aims is to develop biology teaching material integrated religious value on vertebrate subject which fulfill feasibility, readability and effectiveness.The design of the research use Fenrich Instructional Development Cycle Model contains six phase; planning, design, development, implementation, analysis, evaluation, and revision. On this development, the assessment was done by 2 biology lecturers, Islamic lecturer, and biology teacher. The objects of the study are 30 students of X SMA Amanatul Ummah Surabaya. The analysis result and discussion show the average score of feasibility counted by the 2 biology lectures, Islamic lecturer, and biology teacher toward the developed-handbook is $93,1 \%$ on the contains goodness, $95,8 \%$ on language goodness, and $85,1 \%$ on serving goodness component. The students give positive response toward the teaching material that has been developed. This teaching material have low degree or difficulty by $11,1 \%$. The average percentage of readability is $95 \%$. Reliability of teaching plan effectiveness is $98,51 \%$.Based on analysis result, the conclusion is biology teaching material integrated religious value on vertebrate subject which fulfill feasibility, readability and effectiveness.
\end{abstract}

Keywords: development, handbook, integrated religious value, vertebrate.

\begin{abstract}
Abstrak: Penelitian ini bertujuan untuk mengembangkan bahan ajar biologi terintegrasi imtaq pada materi vertebrata yang memenuhi kelayakan, keterbacaan, dan keterlaksanaan. Penelitian ini menggunakan Model Siklus Pengembangan Instruksional Fenrich yang meliputi enam fase yaitu fase perencanaan, perancangan, pengembangan, implementasi, analisis, evaluasi dan revisi. Pada tahap pengembangan, dilakukan penilaian oleh 2 orang dosen biologi, dosen agama, dan guru biologi. Pengambilan data dilakukan kepada 30 siswa kelas X SMA Amanatul Ummah Surabaya. Hasil analisis dan pembahasan menunjukkan nilai rata-rata hasil telaah dua dosen biologi, dosen agama, dan guru biologi terhadap bahan ajar yang dikembangkan adalah sebesar 93,1\% pada kelayakan isi, 95,8\% pada kelayakan kebahasaan, dan 85,1\% pada komponen kelayakan penyajian. Bahan ajar yang dikembangkan memiliki tingkat kesulitan yang sangat rendah yaitu sebesar $11,1 \%$. Nilai rata-rata persentase tingkat keterbacaan bahan ajar adalah 95\%. Reliabilitas instrumen keterlaksanaan RPP adalah 98,51\%. Siswa merespon positif terhadap buku ajar yang dikembangkan.Berdasarkan hasil analisis data, dapat disimpulkan bahwa bahan ajar biologi terintegrasi imtaq pada materi vertebrata memenuhi kelayakan, keterbacaan, dan keterlaksanaan.
\end{abstract}

Kata kunci: pengembangan, bahan ajar, integrasi imtaq, vertebrata.

\section{PENDAHULUAN}

Bahan ajar merupakan seperangkat materi pelajaran (teaching material) yang disusun secara sistematis yang sesuai dengan kompetensi yang akan dikuasai siswa dalam kegiatan pembelajaran. Bahan ajar berfungsi sebagai pedoman bagi guru yang akan mengarahkan semua aktivitas dalam proses pembelajaran substansi kompetensi yang diajarkan pada siswa, serta alat evaluasi pencapaian/penguasaan hasil pembelajaran. Tersedianya bahan ajar yang baik memungkinkan siswa untuk mempelajari suatu kompetensi secara runtut dan sistematis sehingga secara akumulatif mampu menguasai semua kompetensi secara utuh dan terpadu (Depdiknas, 2006:14).

Bahan ajar dinyatakan baik apabila memenuhi tiga kriteria, yaitu (1) validitas, (2) feasibilitas, dan (3) efektivitas. Validitas bahan ajar dinilai atas: (a) validitas konstruksi, kesesuaian isi atau pesan yang terkandung di dalam bahan ajar dengan tuntutan kurikulum dan (b) validitas isi, kebenaran isi atau konsep yang terkandung dalam bahan ajar, terbebas dari miskonsepsi. Feasibilitas bahan ajar menyangkut keterbacaan, kemenarikan, ukuran, dan lain-lain sehingga mudah digunakan oleh pengguna (siswa). Efektivitas bahan ajar adalah instructional effect yang ditimbulkannya setelah digunakan dalam proses pembelajaran. Bahan ajar yang akan digunakan oleh guru untuk mendukung skenario pembelajarannya dan/ atau digunakan siswa sebagai sumber informasi tidak boleh mengandung konsep-konsep yang tidak sesuai 
dengan definisi ilmiah. Bahan ajar tidak boleh memuat materi miskonsepsi.

Kurikulum 2013 membelajarkan aspek pengetahuan dan keterampilan, dan juga mengamanatkan pengintegrasian Kompetensi Dasar aspek spiritual (mendukung Kompetensi Inti sikap spiritual). Pada materi vertebrata memiliki Kompetensi Inti sikap spiritual yaitu menghayati dan mengamalkan ajaran agama yang dianutnya. Kemudian, untuk Kompetensi Dasar yang terdapat pada materi ini adalah mengagumi keteraturan dan kompleksitas ciptaan Tuhan tentang keanekaragaman hayati, ekosistem, dan lingkungan hidup. Dari segi aspek spiritual, pembelajaran biologi dapat dijadikan sebagai wahana dalam menanamkan nilai-nilai akhlak mulia. Hal tersebut didukung sejumlah besar fenomena-fenomena di alam semesta yang termasuk ke dalam ayat-ayat kauniah. Allah befirman dalam Al-Qur'an surat Fushshilat ayat 53, "Kami akan memperlihatkan kepada mereka tandatanda (kekuasaan) Kami di segala wilayah bumi dan pada diri mereka sendiri, hingga jelas bagi mereka bahwa Al-quran itu adalah benar. Tidakkah cukup bahwa sesungguhnya Tuhanmu menjadi saksi atas segala sesuatu?"

Berdasarkan penelusuran peneliti pada sekolahsekolah SMA di kawasan Surabaya, belum ditemukan bahan ajar, khususnya untuk materi vertebrata yang telah mengintegrasikan materi dengan keimanan dan ketaqwaan. Sebagian besar buku-buku yang beredar di masyarakat, terutama buku biologi kelas X SMA hanya berisi pengetahuan saja. Oleh sebab itu, diperlukan pengembangan bahan ajar yang mengintegrasikan materi dengan materi vertebrata untuk mendukung implementasi kurikulum 2013 pada mata pelajaan biologi di kelas X SMA.

Meninjau dari seluruh fenomena tersebut, maka peneliti ingin melakukan penelitian dengan judul "Pengembangan Bahan Ajar Biologi Terintegrasi Imtaq pada Materi Vertebrata sesuai Kurikulum 2013 Kelas X SMA" dengan harapan bahan ajar tersebut nantinya layak digunakan untuk membantu guru sebagai pengajar dan siswa sebagai peserta didik dalam mengintegrasikan materi vertebrata dengan nilai-nilai ajaran agama Islam sesuai dengan aspek sikap spiritual yang terdapat dalam kompetensi inti pada Kurikulum 2013.

\section{METODE PENELITIAN}

Penelitian ini adalah jenis penelitian pengembangan dengan menggunakan siklus pengembangan instruksional fenrich (Fenrich, 2004). Bahan ajar akan divalidasi dari segi kelayakan isi, kebahasaan, penyajian dan komponen imtaq. Selanjutnya, hasil bahan ajar yang dikembangkan diimplementasikan untuk mendapatkan deskripsi keterlaksanaan pembelajaran. Penelitian ini diawali dengan pengembangan bahan ajar yang diawali dengan fase analisis siswa dan kurikulum, fase perencanaan, fase perancangan, fase pengembangan (development), fase implementasi dan fase evaluasi dan revisi. Prosedur penelitian ini mengacu pada model siklus pengembangan fenrich (2004) pada Gambar 1.



Gambar 1. Model Siklus Pengembangan Instruksional Fenrich (Fenrich, 2004, h. 56)

Penelitian dilaksanakan di SMA Unggulan Amanatul Ummah Surabaya pada Semester Gasal Tahun Pelajaran 2014/2015. Subjek dalam penelitian ini adalah siswa kelas X IPA.

Instrumen yang digunakan dalam pengumpulan data terdiri dari lembar validitas bahan ajar, angket tingkat kesulitan bahan ajar, lembar uji keterbacaan bahan ajar, lembar pengamatan keterlaksanaan pembelajaran, lembar pengamatan aktivitas siswa, angket respon siswa, lembar penilaian kemampuan kognitif, dan lembar penilaian diri siswa terhadap sikap spiritual.

Data hasil validitas bahan ajar, tingkat kesulitan bahan ajar, keterbacaan bahan ajar, keterlaksanaan pembelajaran, data pengamatan aktivitas siswa, respon siswa, penilaian diri siswa terhadap sikap spiritual dan kemampuan kognitif siswa dianalisis secara deskriptif.

Persentase dari data validasi bahan ajar diperoleh berdasarkan perhitungan dengan skala likert seperti pada Tabel 1.

Tabel 1. Skala Likert

\begin{tabular}{|l|l|}
\hline Penilaian & Nilai skala \\
\hline Kurang & 1 \\
Sedang & 2 \\
Baik & 3 \\
Sangat baik & 4 \\
\hline
\end{tabular}

(dimodifikasi dari Riduwan, 2010)

Berikut ini adalah rumus yang digunakan dalam perhitungan hasil telaah dari masing-masing komponen kelayakan.

$$
\mathrm{P}(\%)=\frac{\sum \text { skor total semua validator untuk masing }- \text { masing kriteria }}{\text { skor kriteria }} \times 100 \%
$$

Skor kriteria $=$ skor tertinggi $\mathrm{x}$ jumlah aspek dalam kriteria tersebut $\mathrm{x}$ jumlah reviewer 
Hasil analisis lembar telaah digunakan untuk mengetahui kelayakan buku ajar yang dikembangkan dengan menggunakan interpretasi skor. Tabel 2 menunjukkan kriteria interpretasi skor dengan besar persentase penilaian telaah terhadap buku ajar oleh validator adalah sebagai berikut:

Tabel 2. Kriteria Interpretasi Skor

\begin{tabular}{|l|l|}
\hline Presentase & Kategori \\
\hline Angka $21 \%-40 \%$ & Kurang \\
Angka $41 \%-60 \%$ & Cukup \\
Angka $61 \%-80 \%$ & Baik \\
Angka $81 \%-100 \%$ & Sangat baik \\
\hline
\end{tabular}

Respon siswa diukur menggunakan skala Guttman, yaitu skala yang digunakan untuk jawaban yang bersifat jelas (tegas) dan konsisten. Jawaban responden dapat berupa skor tertinggi bernilai (1) untuk jawaban "ya" dan skor terendah bernilai (0) untuk jawaban "tidak". (Riduwan, 2010). Analisis respon siswa dapat dihitung dengan rumus:

$$
\text { Persentase }(\%)=\frac{\text { jumlah siswa yang menjawab ya/tidak }}{\text { jumlah seluruh siswa }} \times 100 \%
$$

Dari hasil analisis angket respon siswa, dapat dilakukan penarikan kesimpulan bahwa buku ajar yang dikembangkan layak digunakan bila interpretasinya $\mathrm{x}$ $\geq 75 \%$ (Riduwan, 2010).

\section{HASIL PENELITIAN DAN DISKUSI}

\section{A. Pengembangan Bahan Ajar Siswa}

Hasil penilaian kelayakan bahan ajar biologi yang terintegrasi imtaq pada materi Vertebrata komponen kelayakan isi, Imtaq, kabahasaan dan penyajian disajikan pada Tabel 3,4,5 dan 6 berturut-turut sebagai berikut.

Tabel 3. Rekapitulasi Penilaian Bahan Ajar Biologi Komponen Kelayakan Isi

\begin{tabular}{|c|c|c|c|c|c|}
\hline \multirow[t]{2}{*}{ No. } & \multirow[t]{2}{*}{ Kriteria } & \multicolumn{2}{|c|}{$\begin{array}{l}\text { Rerata } \\
\text { Penilaian }\end{array}$} & Skor & \multirow[t]{2}{*}{$\begin{array}{l}\text { \% } \\
\text { Kelay } \\
\text { akan }\end{array}$} \\
\hline & & $V_{1}$ & $\mathbf{V}_{2}$ & $V_{3}$ & \\
\hline 1. & Cakupan materi & 4 & 3,5 & 4 & \multirow{6}{*}{96,8} \\
\hline 2. & Akurasi materi & 4 & 4 & 4 & \\
\hline 3. & Kemutakhiran & 4 & 4 & 4 & \\
\hline 4. & $\begin{array}{l}\text { Merangsang } \\
\text { keingintahuan }\end{array}$ & 4 & 4 & 3 & \\
\hline \multicolumn{2}{|c|}{ Jumlah skor } & 16 & 15,5 & 15 & \\
\hline \multicolumn{2}{|c|}{ Skor total } & \multicolumn{3}{|c|}{46,5} & \\
\hline
\end{tabular}

Tabel 4. Rekapitulasi Penilaian Bahan Ajar Biologi Komponen Kelayakan Imtaq

\begin{tabular}{|l|lr|c|c|}
\hline No. & Kriteria & $\begin{array}{l}\text { Rerata } \\
\text { Skor }\end{array}$ & $\begin{array}{l}\text { \% } \\
\text { Kelayakan }\end{array}$ \\
\hline 1. & $\begin{array}{l}\text { Kajian Imtaq yang } \\
\text { disajikan }\end{array}$ & $\begin{array}{r}\text { sesuai } \\
\text { sesuan }\end{array}$ & 93,8 \\
\hline
\end{tabular}

Pengembangan Bahan Ajar Biologi Terintegrasi Imtaq pada

Materi Vetebrata...

\begin{tabular}{|c|c|c|c|}
\hline No. & Kriteria & $\begin{array}{l}\text { Rerata } \\
\text { Skor }\end{array}$ & $\begin{array}{l}\% \\
\text { Kelayakan }\end{array}$ \\
\hline & $\begin{array}{ll}\text { dengan } & \text { materi } \\
\text { Vertebrata } & \end{array}$ & & \\
\hline 2. & \begin{tabular}{lr} 
Materi & Vertebrata \\
yang & terintegrasi \\
Imtaq & dapat \\
mendorong siswa \\
untuk mensyukuri \\
\multicolumn{2}{c}{ ciptaan Tuhan YME }
\end{tabular} & 3,5 & \\
\hline 3. & $\begin{array}{lr}\text { Materi } & \text { Vertebrata } \\
\text { yang terintegrasi } \\
\text { Imtaq } & \text { dapat } \\
\text { mendorong } & \text { siswa } \\
\text { memanfaatkan } & \\
\text { Vertebrata sesuai } \\
\text { dengan ajaran Islam }\end{array}$ & 4,0 & \\
\hline 4. & $\begin{array}{lr}\text { Materi } & \text { Vertebrata } \\
\text { yang } & \text { terintegrasi } \\
\text { Imtaq } & \text { dapat } \\
\text { menambah } & \\
\text { keyakinan } & \text { terhadap } \\
\begin{array}{lr}\text { ayat-ayat } \\
\text { YME }\end{array} & \text { Tuhan } \\
\end{array}$ & 3,5 & \\
\hline & Skor Total & 3,75 & \\
\hline
\end{tabular}

Tabel 5. Rekapitulasi Penilaian Bahan Ajar Biologi Komponen Kelayakan Kebahasaan

\begin{tabular}{|c|c|c|c|c|c|}
\hline \multirow[b]{2}{*}{ No. } & \multirow[b]{2}{*}{ Kriteria } & \multicolumn{3}{|c|}{$\begin{array}{l}\text { Rerata Skor } \\
\text { Penilaian }\end{array}$} & \multirow[b]{2}{*}{$\begin{array}{l}\% \\
\text { Kelaya } \\
\text { kan }\end{array}$} \\
\hline & & $\mathbf{V}_{1}$ & $\overline{V_{2}}$ & $\mathrm{~V}_{3}$ & \\
\hline 1. & $\begin{array}{l}\text { Sesuai dengan } \\
\text { tingkat } \\
\text { perkembangan } \\
\text { peserta didik }\end{array}$ & 4 & 4 & 4 & \multirow{8}{*}{95,8} \\
\hline 2. & Komunikatif & 4 & 4 & 4 & \\
\hline 3. & Lugas & 4 & 4 & 4 & \\
\hline 4. & $\begin{array}{ll}\text { Koherensi } & \text { dan } \\
\text { keruntutan } & \text { alur } \\
\text { pikir } & \end{array}$ & 4 & 4 & 4 & \\
\hline 5. & $\begin{array}{ll}\text { Kesesuaian } & \text { dengan } \\
\text { kaidah } & \text { bahasa } \\
\text { Indonesia } & \end{array}$ & 4 & 4 & 3 & \\
\hline 6. & Penggunaan istilah & 4 & 4 & 4 & \\
\hline \multicolumn{2}{|c|}{ Jumlah skor } & 24 & 24 & 23 & \\
\hline \multicolumn{2}{|c|}{ Skor total } & & 71 & & \\
\hline
\end{tabular}

Tabel 6. Rekapitulasi Penilaian Bahan Ajar Biologi Komponen Kelayakan Penyajian

\begin{tabular}{|c|c|c|c|c|c|}
\hline \multirow[b]{2}{*}{ No. } & \multirow[b]{2}{*}{ Kriteria } & \multicolumn{3}{|c|}{$\begin{array}{ll}\text { Rerata } & \text { Skor } \\
\text { Penilaian } & \end{array}$} & \multirow[b]{2}{*}{$\begin{array}{l}\text { \% } \\
\text { Kelay } \\
\text { akan }\end{array}$} \\
\hline & & $\mathbf{V}_{1}$ & $\mathbf{V}_{2}$ & $\mathbf{V}_{3}$ & \\
\hline 1. & $\begin{array}{l}\text { Teknik } \\
\text { penyajian }\end{array}$ & 4 & 3 & 4 & \multirow[t]{2}{*}{86,5} \\
\hline 2. & Pendukung & 3 & 4 & 4 & \\
\hline
\end{tabular}




\begin{tabular}{|c|c|c|c|c|c|}
\hline \multirow{2}{*}{ No. } & \multirow{2}{*}{ Kriteria } & \multicolumn{2}{|c|}{$\begin{array}{l}\text { Rerata } \\
\text { Penilaian }\end{array}$} & Skor & \multirow{2}{*}{$\begin{array}{l}\% \\
\text { Kelay } \\
\text { akan }\end{array}$} \\
\hline & & $V_{1}$ & $\mathbf{V}_{2}$ & $\mathbf{V}_{3}$ & \\
\hline & $\begin{array}{l}\text { penyajian } \\
\text { materi }\end{array}$ & & & & \\
\hline 3. & $\begin{array}{l}\text { Penyajian } \\
\text { dalam tugas } \\
\text { pembelajaran }\end{array}$ & 3 & 4 & 3 & \\
\hline 4. & $\begin{array}{l}\text { Penyajian } \\
\text { ilustrasi teks } \\
\text { dan gambar }\end{array}$ & 3 & 2.5 & 4 & \\
\hline \multicolumn{2}{|c|}{ Jumlah skor } & 13 & $\begin{array}{l}13, \\
5\end{array}$ & 15 & \\
\hline \multicolumn{2}{|c|}{ Skor total } & \multicolumn{3}{|c|}{41,5} & \\
\hline
\end{tabular}

Setelah dilakukan validasi bahan ajar, komponen kelayakan isi mendapatkan persentase sebesar 96,8\% setelah ditelaah oleh dua dosen biologi, guru biologi dan dosen agama. Analisa ini dilakukan terhadap setiap aspek pada komponen kelayakan isi meliputi cakupan materi, akurasi materi, kemutakhiran, dan merangsang keingintahuan.

Berdasarkan kriteria interpretasi skor, persentase kelayakan isi dalam bahan ajar memiliki kategori sangat baik jika menunjukkan angka $81 \%$ hingga $100 \%$ (Riduwan, 2010). Dengan demikian berarti bahwa bahan ajar yang dikembangkan telah memenuhi komponen kelayakan dari segi isi dengan kategori sangat baik. Hal ini sesuai dengan yang tertera dalam Badan Standar Nasional Pendidikan (BSNP, 2007) mengenai komponen penting yang harus ada dalam penyusunan bahan ajar salah satunya adalah kelayakan isi.

Komponen kelayakan isi memiliki lima sub komponen, yaitu cakupan materi, akurasi materi, kemutakhiran, merangsang keingintahuan, dan mengembangkan nilai iman dan taqwa (BSNP, 2006). Materi disusun sesuai dengan tujuan pembelajaran. Dalam bahan ajar yang dikembangkan, komponen kelayakan pada kriteria mengembangkan nilai iman dan taqwa menunjukkan persentase sebesar 93,8\%. Rekapitulasi penilaian ini dilakukan oleh dosen agama. Hal ini ditunjukkan dengan adanya tujuan pembelajaran yang berkaitan dengan iman dan takwa yaitu menunjukkan rasa syukur atas keteraturan dan kompleksitas ciptaan Tuhan tentang keanekaragaman makhluk hidup.

Sejalan dengan hal tersebut, Kompetensi Inti sikap yang digunakan sebagai pegangan bagi pendidik dalam mengajarkan mata pelajaran menyatakan hendaknya dalam proses pembelajaran, guru mengajarkan pesanpesan spiritual yang terkandung dalam materinya. Dengan kata lain, kompetensi dasar sikap spiritual dikembangkan secara tidak langsung (indirect teaching) saat peserta didik belajar tentang pengetahuan dan keterampilan (BSNP, 2007).

Pemahaman terhadap ayat-ayat Al-Qur'an dalam hubungannya dengan pengembangan ilmu pengetahuan amat erat kaitannya dengan kegiatan pendidikan. Mengubah sikap mental dan perilaku tertentu agar menjadi seorang manusia yang terbina seluruh potensi dirinya sehingga dapat melaksanakan fungsinya sebagai khalifah merupakan tujuan akhir pendidikan. Dalam proses menuju ke arah tersebut diperlukan adanya upaya pengajaran. Dengan kata lain, pengajaran adalah salah satu sarana untuk mencapai tujuan pendidikan. Pelaksanaan pendidikan harus mempertimbangkan prinsip pengembangan ilmu pengetahuan yang tidak semata-mata hanya mengembangkan ilmu pengetahuan itu sendiri, melainkan dapat membantu manusia menangkap hikmah di balik ilmu pengetahuan, yaitu rahasia keagungan Allah SWT. Dalam Kurikulum 2013 inilah tujuan pembelajaran harus ada yang mengarahkan siswa pada kompetensi inti I mengenai sikap spiritual terkait dengan tujuan pendidikan nasional yaitu membentuk peserta didik yang beriman dan bertaqwa.

Integrasi ilmu pengetahuan dan imtaq dalam pembelajaran dapat dilakukan apabila terdapat materi yang dapat mendukung peningkatan imtaq (Rachman et al., 2002: 30). Dalam hal ini diharapkan siswa akan bersyukur ketika menyadari bukti-bukti kesempurnaan makhluk ciptakan Allah sesuai dengan yang tertera dalam Al-Qur'an Surat Al-A'la ayat 1 sampai 3.



Artinya:

"Sucikanlah nama Tuhanmu Yang Maha Tinggi, yang menciptakan lalu menyempurnakan ciptaan-Nya, yang menentukan kadar masing-masing dan memberikan petunjuk" ( Q.S. Al-A'la: 1-3).

Selain itu, tujuan pembelajaran terintegrasi imtaq pada bahan ajar yang kedua adalah memiliki kesadaran untuk senantiasa menjaga dan menyayangi lingkungan sebagai pengamalan ajaran agama. Biologi adalah salah satu dari disiplin ilmu pengetahuan dengan berbagai cabang ilmunya merupakan sunnatullah, menyatu dalam asma dan sifatNya. Oleh karena itu biologi merupakan bagian integral yang tak terpisahkan dari Al-Qur'an. Kajian ilmu biologi banyak memberikan manfaat bagi kehidupan manusia. Namun, tanpa disertai dengan moral yang baik, pemanfaatan biologi dapat dijadikan sebagai senjata biologis pemusnah masal atau pemanfaatan tanpa mempertimbangkan keutuhan ekosistem (Sugiono, 2008). 
Pada komponen kebahasaan memiliki beberapa kriteria yaitu kesesuaian dengan tingkat perkembangan peserta didik, komunikatif, lugas, koherensi dan keruntutan alur pikir, kesesuaian dengan kaidah Bahasa Indonesia dan penggunaan istilah. Komponen ini memiliki kelayakan sebesar 98,6\%. Penyajian bahan ajar yang ditelaah memperoleh persentase sebesar $85,1 \%$.

Berdasarkan kriteria interpretasi skor, persentase komponen kelayakan dalam bahan ajar memiliki kategori sangat baik jika menunjukkan angka $81 \%$ hingga 100\% (Riduwan, 2010). Dengan demikian berarti bahwa bahan ajar yang dikembangkan telah memenuhi komponen kelayakan dari kebahasaan dan penyajian dengan kategori sangat baik. Bahasa yang digunakan untuk mengetahui standar kelayakan yaitu menggunakan bahasa yang sesuai dengan perkembangan peserta didik, komunikatif, lugas, koherensi dan keruntutan alur pikir, kesesuaian dengan kaidah Bahasa Indonesia, dan penggunaan istilah yang konsisten (BSNP, 2006). Komponen pada bahan ajar ini disajikan dengan konsistensi sistematika sajian dalam bab, terdapat pendukung penyajian materi, penyajian tugas proyek dan soal latihan dapat mengukur pemahaman peserta didik terhadap materi yang disajikan (BSNP, 2006). Bahan ajar yang dikembangkan telah memenuhi komponen kelayakan dari segi kebahasaan dan penyajian dengan kategori sangat baik. Bahan ajar ini diujicobakan kepada siswa Kelas X SMA Amanatul Ummah Surabaya yang berjumlah 30 siwa pada tanggal 6 sampai 8 Juli 2015 . Siswa menjawab angket respon siswa untuk mengetahui kepraktisan dari bahan ajar yang telah dikembangkan.

Respon siswa diukur menggunakan skala Guttman, yaitu skala yang digunakan untuk jawaban yang bersifat jelas (tegas) dan konsisten yang dinyatakan berupa skor tertinggi bernilai (1) untuk jawaban ya dan skor terendah bernilai (0) untuk jawaban tidak. Berdasarkan análisis angket respon siswa, bahan ajar yang dikembangkan layak digunakan bila interpretasinya $\mathrm{x} \geq 75 \%$ (Riduwan, 2010). Dengan demikian bahan ajar yang dikembangkan telah layak digunakan karena memenuhi interpretasi $\mathrm{x} \geq 75 \%$ dari segi respon siswa.

Fitur-fitur bahan ajar yang disajikan pada bagian awal adalah fitur "apa yang akan kamu pelajari", fitur "mengapa materi ini penting", kosa kata baru, pendahuluan, dan tujuan pembelajaran. Sedangkan pada bagian isi, fitur yang ada adalah fitur peta konsep, uraian materi, fitur "tahukah kamu?", bio-lab, Net-bio, kisah hikmah, mari berpikir, aktivitas bio, tugas proyek, tips. Kemudian pada bagian akhir meliputi konsep penting, evaluasi dan glossarium. Banyaknya fitur pada bahan ajar yang dikembangkan bertujuan untuk memotivasi siswa dalam memahami bahan ajar.
Motivasi merupakan satu unsur paling penting dari pembelajaran karena menentukan seberapa banyak siswa akan belajar dan menyerap informasi yang disajikan kepada mereka dari suatu kegiatan pembelajaran. Motivasi yang tinggi akan membuat siswa menggunakan proses kognitif yang lebih tinggi dalam mempelajari suatu materi, sehingga siswa akan menyerap dan mengendapkan materi itu dengan lebih baik (Nur, 2008). Selain itu, adanya peta konsep tersebut diharapkan dapat membantu siswa untuk lebih memahami hubungan antar konsep pada materi vertebrata.

Pada respon siswa terhadap komponen penyajian konsep menunjukkan persentase sebesar $100 \%$ siswa senang dengan bahan ajar biologi yang terintegrasi imtaq. Alasan yang siswa kemukakan dalam mendukung komponen penyajian konsep tersebut adalah dengan adanya bahan ajar biologi yang terintegrasi imtaq, dapat mengetahui kalamullah yang terintegrasi dalam materi vertebrata, memberikan kesadaran bagi siswa bahwa dengan diciptakannya hewan di dunia banyak membantu dan memberikan manfaat bagi manusia, memberikan kesadaran bagi siswa bahwa hewan itu juga merupakan makhluk allah yang harus dirawat dan disayangi, dalam penciptaan segala jenis hewan yang begitu sempurna dilengkapi dengan cara pertahanan diri, adaptasi, dan berkembangbiak menunjukkan kebesaran Sang Pencipta, sebagai salah satu bentuk syukur kepada Allah adalah dengan cara meningkatkan ibadah kepada Allah.

Siswa-siswa menyetujui bahwa bahan ajar yang dikembangkan dapat mendorong siswa untuk mensyukuri ciptaan Tuhan YME. Hal ini ditunjukkan dengan persentase respon siswa terhadap fitur Imtaq sebesar $100 \%$. Fitur Imtaq juga dapat mendorong siswa untuk melestarikan hewan sesuai dengan ajaran agama Islam. Fitur Imtaq juga dapat menambah keyakinan akan kebesaran Tuhan YME, materi dari bahan ajar ini dapat mendorong diri siswa untuk lebih meningkatkan iman dan taqwa kepada Allah. Siswa berpendapat bahwa integrasi imtaq ke dalam materi vertebrata dapat membantu siswa dalam bertafakur terhadap ayat-ayat Allah dan ayat-ayat alam untuk meningkatkan iman dan taqwa kepada Allah. Persentase respon positif siswa bernilai sangat positif pada persentase berkisar antara $81-100 \%$ (Ratumanan, 2003). Hal ini berarti siswa memberikan respon yang sangat positif bahwa bahan ajar yang dikembangkan dapat mendorong siswa untuk mensyukuri ciptaan Tuhan YME. Program integrasi penanaman rasa syukur ini dimaksudkan untuk membuka peluang kepada peserta didik agar memiliki kesadaran nilai yang tinggi (Kohar, 2010).

Melalui model integrasi ini guru dapat mengembangkannya menjadi bahan ajar yang sesuai 
dengan nilai imtaq yang akan ditanamkan. Sebagai gambaran, berikut ini adalah contoh pengintegrasian nilai imtaq dalam pembelajaran biologi untuk menyadarkan siswa agar selalu mensyukuri nikmat yang telah diberikan Allah kepada kita. Di dunia ini, terdapat berjuta-juta spesies ciptaan Allah yang beraneka ragam bentuk dan jenisnya. Ini adalah salah satu tanda-tanda kebesaran Allah. Jadi, laut dan segala hewan yang terdapat di dalamnya, yang mencapai lebih dari sejuta spesies, diciptakan untuk kita. Allah telah berfirman,



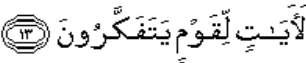

"Dan Dia menundukkan apa yang ada di langit dan apa yang ada di bumi untukmu semuanya sebagai rahmat dari-Nya" (Q.S. Al-Jatsiyah: 13).

Pada komponen bahasa menunjukkan $83,3 \%$ ratarata dari siswa memberikan respon positif terhadap bahan ajar biologi yang dikembangkan. Dari hasil penilaian terhadap bahan ajar yang dilakukan oleh dua dosen biologi, dosen agama, guru biologi, dan respon siswa Kelas X SMA Unggulan Amanatul Ummah Surabaya setelah menggunakan bahan ajar biologi terintegrasi imtaq pada materi Vertebrata layak digunakan dalam kegiatan pembelajaran sebagai penunjang Kurikulum 2013.

\section{B. Tingkat Kesulitan Bahan Ajar}

Tingkat kesulitan bahan ajar yang dikembangkan adalah sangat rendah dengan persentase sebesar $11,1 \%$. Berdasarkan tabel kriteria tingkat kesulitan bahan ajar, persentase $\geq 20,9 \%$ menunjukkan tingkat kesulitan sangat rendah yang berarti bahan ajar tersebut mudah dipahami (Hasanah, 2012). Dengan demikian, bahan ajar yang dikembangkan telah memenuhi tingkat keterbacaan dengan kategori sangat mudah dipahami oleh siswa. Rendahnya tingkat kesulitan bahan ajar ini juga disebabkan pernyataan yang digunakan untuk uji tingkat kesulitan adalah jumlah kalimat yang tidak dipahami oleh siswa, bukan jumlah kata. Pada saat siswa menemukan kata-kata baru atau masih asing, meskipun tidak memahami arti dari kata-kata tersebut siswa memahami makna secara keseluruhan dari kalimat.

\section{Tingkat Keterbacaan Bahan Ajar}

Tingkat keterbacaan bahan ajar adalah $95 \%$. Mengacu pada kriteria tingkat keterbacaan Taylor (1953), persentase keterbacaan bahan ajar di atas 60\% berada pada level bebas yang berarti mudah dibaca dan dipahami. Hal ini berarti bahan ajar yang dikembangkan telah memenuhi keterbacaan bahan ajar. Mudahnya materi ini bagi siswa disebabkan materi vertebrata sangat erat dengan kehidupan siswa seharihari. Ketika siswa belajar dari hewan-hewan peliharaan yang ada di lingkungannya, konsep-konsep tersebut akan masuk ke register penginderaan, kemudian memori jangka pendek dan akhirnya memori jangka panjang. Menurut teori konstruktivis, dari aktivitas inilah akan terbangun suatu skemata pada otak siswa. Ketika struktur skemata ini terstimulasi oleh informasi baru tentang konsep-konsep pengklasifikasian vertebrata, maka siswa akan memahami materi yang terkait dengan mudah (Nur, 2008)

\section{Efektivitas Penggunaan Bahan Ajar \\ 1. Keterlaksanaan Pembelajaran}

Berdasarkan Hasil pengamatan yang dilakukan oleh dua orang guru terhadap keterlaksanaan pembelajaran menghasilkan skor rata-rata pada pendahuluan, kegiatan inti, penutup dan pengelolaan KBM berturut-turut sebesar 3,50, 3,26, 3,62, dan 3,50. Untuk setiap aspek penilaian diambil rata-rata persentase hasil penilaian dari pengamat, kemudian ditentukan kategori kualitas keterlaksanaannya. Berdasarkan kategori kualitas keterlaksanaan pembelajaran, suatu pembelajaran dikatakan baik jika memiliki kategori berkisar antara 3.1 sampai 4 (Hasanah, 2008). Dengan demikian, kemampuan guru (peneliti) dalam melaksanakan pembelajaran berkategori baik.

\section{Aktivitas Siswa}

Urutan aktivitas siswa selama dua kali pertemuan dari persentasenya terbesar hingga terkecil berturutturut adalah menyampaikan pendapat atau mengkomunikasikan informasi kepada kelas atau guru $(15,05 \%)$, melakukan pengamatan (14,75\%), mendiskusikan tugas $(12,15 \%)$, bertanya pada guru $(6,8 \%)$. Jenis-jenis aktivitas tersebut menggambarkan bahwa pembelajaran ini berpusat pada siswa dengan persentase keseluruhan $81,7 \%$. Dengan demikian bahan ajar yang dikembangkan dapat membuat siswa aktif.

Adanya kecenderungan pembelajaran yang berpusat pada siswa ini akan memberikan sumbangan yang positif terhadap prestasi belajar siswa, misalnya terhadap hasil belajar kognitif. Hal ini sesuai dengan yang dikatakan oleh Sudjana (2005) bahwa ciri pengajaran yang berhasil salah satu diantaranya dilihat dari kadar kegiatan siswa belajar. Makin tinggi kegiatan belajar siswa, makin tinggi peluang berhasilnya pengajaran.

\section{Tes Hasil Belajar}

Berdasarkan hasil penilaian ketuntasan hasil belajar siswa didapatkan bahwa $100 \%$ siswa dinyatakan tuntas. Tes hasil belajar kognitif bertujuan untuk mendeskripsikan sejauh mana siswa dapat mencapai 
indikator pencapaian kompetensi. Secara individu, seorang siswa dapat dikatakan tuntas apabila persentase (p) indikator yang dicapai sebesar $\geq 75 \%$ dan secara klasikal apabila $\geq 70 \%$ individu tuntas (Hasanah, 2008). Dengan demikian, siswa dapat mencapai seluruh indikator kompetensi yang terdapat dalam bahan ajar yang dikembangkan. Keberhasilan siswa dalam menuntaskan semua indikator ini menunjukkan bahwa siswa termotivasi untuk belajar. Dengan adanya motivasi, menurut teori belajar sosial Bandura (Nur, 1998), maka siswa sebagai pembelajar akan lebih menaruh perhatian (atensi), mengingat (retensi), dan memproduksi.

Kemampuan kognitif adalah kemampuan yang dimiliki seseorang untuk mengingat dan memahami pengetahuan. Dalam teori belajar konstruktivis, siswa itu sendiri yang harus secara pribadi menemukan dan menerapkan informasi kompleks jika siswa membuat informasi itu menjadi miliknya sendiri. Salah satu prinsip terpenting dari psikologi pendidikan adalah guru tidak dapat hanya semata-mata memberikan pengetahuan kepada siswa. Siswa harus membangun pengetahuan di dalam benaknya sendiri dengan cara mengajarkan informasi secara bermakna dan relevan bagi siswa(Nur, 2008). Guru dapat membantu proses ini, dengan cara-cara mengajar yang membuat informasi menjadi sangat bermakna dan relevan bagi siswa, dengan mengintegrasikan materi vertebrata dengan nilai-nilai imtaq.

Beberapa penguatan untuk mempertinggi motivasi telah diberikan selama proses pembelajaran. Penguatan tersebut antara lain diberikan dengan menyajikan kisah hikmah dan fitur imtaq yang berhubungan dengan materi vertebrata. Keberhasilan ini juga ditunjang dengan adanya beberapa kegiatan dalam pembelajaran yang bertujuan melatihkan keterampilan proses, misalnya kegiatan mengamati, mengelompokkan, dan mempresentasikan hasil pengamatan. Keterampilan melakukan pengamatan yang disajikan dalam bahan ajar yaitu mengamati karakteristik kelima kelas vertebrata. Keterampilan melakukan pengelompokan dilakukan dengan mengelompokkan gambar-gambar vertebrata ke dalam lima kelas.

\section{Penilaian Diri Siswa terhadap Sikap Spiritual}

Pada penelitian ini dilakukan pengambilan data melalui penilaian diri siswa terhadap sikap spiritual yang mereka miliki setelah menggunakan bahan ajar. Penilaian ini memberikan kesempatan kepada siswa untuk merefleksi sikap spiritual yang terdapat dalam diri mereka. Beberapa pernyataan untuk penilaian diri siswa setelah mempelajari materi hewan vertebrata adalah mengagumi keteraturan dan kompleksitas ciptaan Tuhan, menyadari keberadaan Tuhan yang mengatur segala sesuatunya, menyayangi hewan sebagai makhluk ciptaan Tuhan, berperan serta dalam menjaga kelestarian makhluk hidup. Semua makhluk hidup di bumi ini senantiasa bertasbih kepada Allah. Hewan dan tumbuhan diciptakan untuk kepentingan manusia. Mereka senantiasa bertasbih kepada Allah. Adapun manusia yang memanfaatkan semua makhluk itu, terkadang mereka lalai untuk mengingat Tuhannya dan di sisi lain durhaka kepada-Nya (Thayyarah, 2013: 563).

Pengintegrasian nilai-nilai sikap dan karakter dalam pembelajaran perlu mempertimbangkan beberapa hal, di antaranya adalah karakteristik materi pelajaran dan model pembelajaran yang digunakan. Hal ini sesuai dengan Sulistyowati (2012) yang menyatakan fokus penanaman nilai-nilai diupayakan cocok atau dekat dengan karakteristik materi pelajaran. Nilai-nilai yang dikembangkan pada akhirnya harus sesuai dengan karakteristik mata pelajaran. Mata pelajaran biologi dipandang sesuai untuk menanamkan nilai-nilai iman dan taqwa.

\section{KESIMPULAN}

\section{A. Simpulan}

Berdasarkan hasil analisis data yang telah dipaparkan bahan ajar yang telah dikembangkan setelah diteliti oleh Dosen Biologi, Dosen Agama, dan Guru Biologi dinyatakan sudah memenuhi kriteria penulisan bahan ajar dari BSNP. Setelah bahan ajar diterapkan dalam pembelajaran dinyatakan memiliki tingkat keterbacaan yang tinggi dan memiliki kualitas keterlaksanaan dengan kategori baik.

B. Saran

Perangakat pembelajaran yang dikembangkan dapat digunakan sebagai alternatif untuk meningkatkan hasil belajar siswa pada materi IPA yang terkait.

\section{REFERENSI}

Depdiknas. (2006). Pedoman Mimilih dan Menyusun Bahan Ajar. Jakarta: Depdiknas.

Depdiknas. (2008). Penilaian Hasil Belajar. Jakarta: Depdiknas.

Depdiknas. (2008). Kamus Besar Bahasa Indonesia. Jakarta: Balai Pustaka.

Halim, T. (2007). "Islamic Education Teachers' Perceptions of The Teaching of "Akhlaq" in Malaysian Secondary School". Journal of Moral Education. Vol. 36 No.3. pp. 371-386.

Hasan, N. (2012). "Education, Young Islamists and Integrated Islamic Schools in Indonesia". Indonesian Journal for Islamic Studies. Vol. 19 No. 1. pp. 77-111.

Keeton, W. (1993). Biologycal Science 5th ed. USA: W.W. Norton \& Company, inc.

Kemendikbud. (2013). Standar Kompetensi Lulusan, Kompetensi Inti, dan Kompetensi Dasar pada Kurikulum 2013. Jakarta. 
Nur, M. (2008). Pengajaran Berpusat kepada Siswa dan Pendekatan Konstruktivis dalam Pengajaran. Surabaya : Pusat Sains dan Matematika Sekolah.

Nur, M. (2012). Pemotivasian Siswa untuk Belajar. Surabaya : Pusat Sains dan Matematika Sekolah.

Rachman, dkk. (2002). Penerapan Pengajaran IPTEK Bermuatan IMTAQ, Konsep dan Aplikasi di Sekolah. Jakarta: PT. Gunara Karya.

Ratumanan, T. (2011). Penilaian Hasil Belajar. Surabaya: Unesa University Press.

Riduwan. (2010). Skala Pengukuran Variabel-variabel Penelitian. Bandung: Penerbit Alfabeta.

Sudjana, N. (1992). Penilaian Hasil Proses Belajar Mengajar. Bandung: Remaja Rosdakarya.
Sugiono. (2008). Metode Penelitian Pendidikan Pendekatan Kuantitatif, Kualitatif dan R\&D. Bandung: Alfabeta.

Sulistyowati, E. (2012). Implementasi Kurikulum Pendidikan Karakter. Jakarta: Citra Adi Pratama.

Thayyarah, N. (2013). Buku pintar Sains dalam ALQuran Mengerti Mukjizat Ilmiah Firman Allah. Jakarta: Zaman.

Tuckman, B. (1978). Conducting Educational Research Second Edition. New York: Harcourt Bruce Javanovich.

Ville, C. (1994). General Zoology 6th ed. Philadelphia: Sounders College Pub. 